NBER WORKING PAPER SERIES

\title{
TRADE AND ENVIRONMENT BEYOND SINGAPORE
}

John Whalley

Working Paper 5768

\author{
NATIONAL BUREAU OF ECONOMIC RESEARCH \\ 1050 Massachusetts Avenue \\ Cambridge, MA 02138 \\ September 1996
}

An earlier version of this paper was presented at a conference on "The Multilateral Trading System in a Globalizing World," Maui, 7-9 August 1996, organized by the East-West Center, Honolulu and the Korean Development Institute. It draws on recent joint work in this area with Peter Uimonen (Uimonen and Whalley (1996) and also a recent essay of my own (Whalley (1996a), especially Section III)). I am grateful to Dan Esty, Joon-Han Kim, Jim Roumassett, Peter Uimonen, and conference participants for comments, and to Lisandro Abrego for research support under an ESRC award at Warwick for a project on Fiscal Policy and the Environment, on which the paper also partly draws. This paper is part of NBER's research program in International Trade and Investment. Any opinions expressed are those of the author and not those of the National Bureau of Economic Research.

(C) 1996 by John Whalley. All rights reserved. Short sections of text, not to exceed two paragraphs, may be quoted without explicit permission provided that full credit, including $\odot$ notice, is given to the source. 
NBER Working Paper 5768

September 1996

\title{
TRADE AND ENVIRONMENT \\ BEYOND SINGAPORE
}

\begin{abstract}
This paper discusses the likely evolution of the trade and environment issue in the World Trade Organization after the upcoming ministerial meeting in Singapore this December. It makes a number of points. Progress within the GATT/WTO on this issue looks likely to be slow and painfully incremental rather than bold as environmental groups would wish to see. The paper also argues that despite (and beyond) Singapore, one has to go further than the GATT/WTO to see the potential evolution of the trade and environment issue. Developments seem likely to be driven in the next few years as much by factors outside the GATT/WTO as well as within it, as new global environmental arrangements, some with potentially large trade implications (such as carbon emission limitation agreements), emerge.
\end{abstract}

John Whalley

Department of Economics

Social Science Centre

University of Western Ontario

London, Ontario N6A 5C2

CANADA

and NBER

NEVILL@SSCL.UWO.CA 


\section{INTRODUCTION}

Much, if not most, of the substantial recent literature on trade and environment (see Anderson and Blackhurst (1992), Beghin et al. (1994), Dean (1992), Esty (1994), Runge (1994), Ulph (1994) and Whalley (1991)) has largely concerned itself with the issue of whether policy linkage between trade and the environment can, in some sense, be justified. Is there a rationale for special trade rules to reflect environmental concerns? When does more trade help or hurt the environment? Should countries be allowed to use protection to achieve environmental goals? Should trade provisions in global environmental treaties be agreed to, even if they override provisions of trade treaties?

In contrast, this paper accepts that trade-environment linkage has entered the trading system, if for no other reason than that a natural instrument linkage exists, since (actual or threatened) trade measures can support transnational environmental objectives of importing countries and (although little discussed) environmental actions can, in principle, also support trade objectives of exporting countries (see Copeland and Taylor (1995)). Such linkage was implicitly accepted at the 1994 Marrakesh meeting that concluded the Uruguay Round, when a GATT/WTO Committee on Trade and Environment (CTE) was established. This Committee is to present its initial report at the first WTO ministerial meeting to be held in Singapore, December 9-13th 1996, and how this linkage will be reflected in the wider post Singapore trading system now seems a more pertinent issue rather than whether a justification for linkage exists.

The paper makes a number of points. Both because of the technical problems and wider precedents involved with any modifications to the GATT/WTO for environmental considerations, and the North-South divisions generated by the issue, 
progress within the GATT/WTO on this issue looks likely to be slow and painfully incremental rather than bold as environmental groups would wish to see. The mandate of the Committee on Trade and Environment for its Singapore report is largely limited to exploring what are the important environmental trade linkages. Little by way of new substantive proposals can be expected from it in Singapore.

Indeed, even taken largely as a GATT/WTO issue, there seem to be no widely agreed upon feasible options as ways to proceed; all proposals for ways forward to GATT/WTO trade and environment reform offered thus far seem to encounter problems. Advocacy that a future WTO Trade Round should be lead by the trade and environment issue (as a 'Green Round') seems not to reflect a realistic assessment both of where things stand in GATT/WTO on the issue, and the elements of reciprocity needed to drive a new Round forward.

The paper also argues that despite (and beyond) Singapore, one also has to go further than the GATT/WTO to see the potential evolution of the trade and environment issue. Developments on the trade and environment issue seem likely to be driven in the next few years as much by factors outside the GATT/WTO as well as within it, as new global environmental arrangements, some with potentially large trade implications (such as carbon emission limitation agreements), emerge. This has already arisen in the CTE with discussion of how to treat trade provisions of existing and new multilateral environmental agreements (MEA)s, such as the Montreal protocol, under the GATT/WTO. A credible argument is that the focus thus far on trade and environment issues of symbolic but limited quantitative significance in the trade and environment debate seems poised to change as discussion (outside of GATT/WTO) of 
a possible global environmental measures with potentially large trade effects accelerates.

The paper concludes by reemphasizing the potential the trade and environment issue has revealed for reigniting the recently dormant North-South divide on trade. Developing countries see trade and environment as a discussion of how trade barriers might go up against them and slow their growth and development, all in the name of meeting environmental objectives espoused by vocal NGOs in the developed world. Some of them use language such as 'green' or 'eco' imperialism, and argue that they should instead be compensated for showing environmental restraint. In contrast, environmental groups in the developed world argue that environmental issues are so serious that these should be the dominant considerations in the setting of the global policy framework, rather than trade concerns. This is a conflict that seems likely to intensify.

In summary, trade and environment remains an issue in flux, and one which is unlikely to be resolved quickly either in Singapore or through subsequent GATT/WTO negotiation. Also to treat trade and environment as solely a GATT/WTO issue risks missing the wider potential significance of environmental policy issues for the trading system; and its ability to resurrect North-South divisions in the trading system. This is especially the case given the complicating precedents the issue raises for other types of future negotiable trade linkages (such as labour standards). 


\section{THE TRADE AND ENVIRONMENT ISSUE, THE WTO, AND THE URUGUAY ROUND}

\section{General Considerations}

The trade and environment issue is one that has come to have high profile in both the trade and the environment communities in recent years. In reality, there is no single issue, but instead a series of inter-related subissues which have agglomerated to fuel an ongoing debate as to what should be done about trade and environment linkage both within the framework of the WTO and more broadly.

At one level, consensus over possible trade and environment linkage derives from the argument, made early on in the debate, that increased trade inevitably implies increased consumption and production, and hence, lowered environmental quality. This theme was reflected in Congressional debates in 1991 and 1992 on NAFTA as it went through its various stages, where extreme environmental problems in the Maquiladora zone, including large untreated discharges into rivers, high infection rates in US border communities attributed to shared US-Mexican aquifers, and other related problems, were seen as inevitably worsening under a NAFTA with yet more US-Mexican trade. ${ }^{1}$

This view that environmental worsening necessarily follows from increased trade is, however, now widely seen as overly simplistic ${ }^{2}$. In the last few decades, developing countries who have been more outward-oriented in their trade policies (such as Korea

\footnotetext{
${ }^{1}$ Leonard and Christensen (1991) strongly made these arguments.

${ }^{2}$ However, Copeland and Taylor (1994) show how a simple static model of North-South trade can be - used to examine linkages between national income, pollution, and international trade and produce results along these lines. Two countries produce a continuum of goods, each differing in pollution intensity. They show that the higher income country chooses stronger environmental protection and specializes in relatively clean goods. By isolating the scale, composition, and technique effects of international trade on pollution, they also show that free trade increases world pollution. An increase in the Rich North's production possibilities increases pollution, while a similar growth in the poor South lowers pollution; and unilateral transfers from North to South reduce worldwide pollution.
} 
compared to, say, India up to the late 1980s) seem to have achieved higher rather than lower environmental standards. In part, this is due to their need to sell into higher income markets with higher environmental standards, which has required them to produce higher environmental standard products. In achieving high growth rates for significant periods of time, and hence higher living standards, these same countries also seem to have witnessed a clear positive impact on environmental quality, reflecting, in part, the income elasticity of their own demand for environmental quality. OECD countries' standards for air and water quality are also considerably higher today than they were 50 years ago (again due to higher incomes, and a positive income elasticity of demand for environmental quality), even though these same economies now trade considerably more as a percentage of GDP than formerly. The GATT (1992a) Annual Report built on these observations to argue, that, firstly, because gains are achievable through trade, real incomes will rise with increased trade; and, secondly, that if these income gains are spent on environmental protection, higher rather than lower environmental quality will result

At quite another level, debate on trade and environment linkage centres on the claim that environmental problems are now so serious that new and much needed environmental policy cannot be allowed to be thwarted by concerns over trade policy ${ }^{3}$. The argument is that the use of trade-restricting measures on environmental grounds should be allowed, even if presently not sanctioned by GATT/WTO. Thus, special trade promotion devices related to environmental objectives (such as export subsidies for pollution control equipment) should be allowed; trade restrictions which offset the effect of low environmental standards are justifiable; and provisions contained in

\footnotetext{
${ }^{3}$ See Shrybman $(1989,1990)$.
} 
existing trade treaties (such as GATT/WTO, or the Treaty of Rome) should not preclude the use of new environmental arrangements, simply on grounds of precedent. The line of argument is that what is needed is to develop appropriate global management strategies for scarce environmental resources, and that trade policy is a key supporting mechanism to implement such resource management, rather than a policy to be decided upon solely on trade considerations.

The counter arguments to this reflect the contention that the benefits of an open trading system in the form of gains from trade have been slowly built up over 50 years of multilateral negotiation, and should not be easily surrendered to new protectionism sanctioned by environmental concerns ${ }^{4}$. Any special treatment for the environment under existing trade rules is also seen as setting a dangerous precedent A domino theory of the trading system is sometimes raised; i.e., that special treatment for one issue will lead to special treatment for other issues, with, eventually, a disappearance in generality of the rule regime in the trading system as we know it today. Reinforcing these concerns is the risk of environmental capture; i.e. that trade policy could become more protectionist, not due to genuine environmental considerations motivating trade policy, but rather from protectionist interests using environmental arguments for their own ends and legitimizing their narrow sectional interests by appeal to environmental rationales

\footnotetext{
${ }^{4}$ See, for instance, Bhagwati (1993).

${ }^{5}$ See the analytical discussions of this new political economy dimension to trade policy in Hillman and Ursprung (1994).
} 


\section{The WTO}

Within the GATT/WTO, the trade and environment issue has also steadily grown in profile in recent years with the development of the wider trade and environment debate outlined above ${ }^{6}$. In its first forty years relatively few environmental cases came before GATT dispute settlement, and the only (somewhat oblique) environmental content of GATT contained in Article XX remained little clarified by dispute case resolution ${ }^{7}$.

A central event in changing this situation was the report of the 1991 GATT panel requested by Mexico following US trade actions based on the practices of tuna fishermen off the Mexican west coast, and which subsequently ruled in Mexico's favour. The issue was that tuna were being caught in nets which incidentally entangled dolphins, causing some of the dolphins to be killed. The United States had made repeated representations to Mexico to reduce the number of dolphins killed in these tuna catches. Appealing to US legislation under the Marine Mammal Protection Act, Earth Island Institute, a California nonprofit group, moved in 1990 to ban the importation of canned, frozen and fresh tuna into the US from 5 countries (Mexico, Panama, Venezuela, Ecuador and Vanuatu). The US also implemented a labelling requirement under this law that set out the conditions under which canned tuna sold in the United States could be described as caught in a dolphin-friendly manner.

- ${ }^{6}$ See Charnovitz (1992).

${ }^{7}$ Appendix C of Esty (1994) outlines both previous GATT cases, and relevant US and EU case law. Some of the earlier GATT cases which touched on environmental issues involved excise duties on imported petroleum and products in the US to fund environmental clean up (the 1971 Superfund case); Canadian restrictions on export of unprocessed fish products from the West Coast fishery (1988), and import bans on cigarettes in Thailand (1990). 
The request for a panel by Mexico and the subsequent panel decision in Mexico's favour attracted widespread attention because it was the first time that a GATT panel was asked to rule on an environmental issue in this way. There were public representations made in Geneva from environmental groups protesting the case and emphasizing what they saw as the anti-environment nature of the GATT. In their view concern for dolphins, not profit, should have been the driving force behind trade policy in the case.

Mexico based its case on two separate arguments. The first was that the US had no rights under GATT to impose such a trade ban. The United States argued that under Article $\mathrm{XX}(\mathrm{b})$ of the GATT it had rights to use trade bans to protect endangered species. The Mexican argument was that were no endangered species at issue; in this case the only point of contention was the nature of the fishing methods used. The Mexicans also appealed the US labelling condition as to when canned tuna could be displayed with a logo indicating that dolphin-friendly methods were used to catch the tuna, on the grounds that this would involve a violation of the mark-of-origin provisions of the GATT under Article IV, which only requires an indication of country of origin.

Following the tuna-dolphin panel report in favour of Mexico ${ }^{8}$, dissatisfaction grew on GATT's position on trade and environment issues on several fronts. Environment groups saw GATT as anti-environment since it did not uphold the use of a trade

\footnotetext{
${ }^{8}$ The panel finding on behalf of Mexico ruled that the US ban was a violation of GATT Article III, and - that the Article XX exceptions in GATT could not be applied on an extraterritorial basis ruling them inapplicable in this case. However, the panel report ruled in favour of the US on the labelling issue. The panel-report was not pushed forward to adoption by the GATT Council for a variety of reasons, including Mexico's then emerging NAFTA negotiation; so the EC subsequently brought a second complaint on tuna-dolphin dealing with import bans in the US Marine Mammal Protection Act from third countries who trade with countries against whom primary actions are taken. The panel report (Tuna-Dolphin II) in 1994 ruled against the US, but on somewhat different grounds. See Esty (1994) pp.268-269.
} 
restricting measure to limit incidental dolphin kills. The US Congress saw GATT as overriding the content of domestic US legislation to protect mammals; and more broadly the environmental content of GATT was seen as vague, weak, and in need of clarification and repair. The extremely limited environmental content of the Uruguay Round decisions (reflecting the 1986 negotiating mandate) intensified these concerns, as did the absence of any reference to the environment in the founding charter of the WTO.

\section{The Uruguay Round}

Despite the profile of the trade and environment issue in the mid to late stages of the Uruguay Round ${ }^{9}$, the decisions from the Round do not deal directly with trade and environment issues since they were not formally part of the negotiating mandate. Much was made by environmental groups of the observation that the word 'environment' did not appear in the Draft Final Act from the Round (the Dunkel Text), which, including tariff schedules, ran to some 26,000 pages of text ${ }^{10}$. Also, the failure of the decisions establishing the WTO to set out future environmental objectives was seen as a chance squandered, and maybe lost for decades, to centrally address the trade and environment issue and establish broad principles in this area to guide the WTO in its future work.

Nonetheless, trade and environment issues were important in developments running parallel to the negotiations themselves, and in particular played a role in defining the

- ${ }^{9}$ A number of events contributed to raising the profile of trade and environment (virtually unheard of at its launch in Punta del Este in 1986) during the later part of the Uruguay Round besides the tuna/dolphin dispute. These included the Earth Summit at Rio in June 1992; the vocal opposition of environmentalists to the NAFTA, and the efforts of environmental groups to block adoption of both the NAFTA and the Uruguay Round decisions in the US.

${ }^{10}$ For a summary of the Uruguay Round agreements, see Whalley and Hamilton (1996). 
work program for the WTO following the Round. Also, as Uimonen (1995) argues, it is not the case that the Uruguay Round decisions are free of environmental implications The Round includes agreements which discipline the trade restricting effects of standards and regulations which have environmental implications, and the agreements on subsidies, countervailing duties and intellectual property rights all have implications for environmental issues.

At a more technical level, the sanitary and phytosanitary measures and technical barriers to trade (TBT) agreements address problems raised by a number of contentious environmental and trade cases ${ }^{11}$. Their objective was to minimize the extent to which standards and regulations can have negative effects on trade, or act as disguised trade barriers, while still permitting GATT contracting parties to adopt or maintain standards that are necessary for the protection of human, plant, and animal life and health.

In the technical barriers to trade agreement, measures include those for environmental protection, as well as those regulations which apply to production and process methods (PPMs.) Each of these agreements defines a national treatment obligation as well as a necessity test, with the aim of minimizing adverse effects of measures taken, much like in GATT Article XX, with loose harmonization agreements for each of the two.

As Uimonen notes, the TBT agreement could prove a catalyst for future environmental trade because the Uruguay Round disciplines in this area seemingly restrict domestic policies rather than border measures. European countries, for - instance, have been playing a leading role in developing new regulations covering waste

\footnotetext{
${ }^{11}$ Including the Canadian beer can case which involved a new environmental levy on beer packaged in cans. For details, see GATT (1992b) Focus 91, p.2
} 
production and recycling, which include waste take-back schemes requiring producers to either take back their packaging waste for disposal or recycling, or pay fees to local authorities to accomplish the same objective, and these could be affected.

The Uruguay Round Subsidies Agreement makes several changes to earlier trade rules, and with potentially significant implications for environmental issues. The approach is one of recognizing the rights of contracting parties to protect themselves through the use of PPMs and related subsidies, while avoiding misuse of countervailing measures of protection. The Agreement offers a definition of subsidy, previously not contained in the GATT, in the form 'specific'12 subsidies, and classifies them according to three categories. The Agreement also lists general subsidies characterized by government financial contributions as nonspecific and nonactionable subsidies; thus nonspecific environmental subsidies are now permitted.

On other environmentally related matters, the Uruguay Round generated results with varying degrees of ambiguity. In the area of standards, the thrust of the agreements from the Round is to discipline trade barriers, while allowing for differences in non-border measures. Exactly how much discipline will be exerted on national regulations, especially in the case of sanitary and phytosanitary standards, and what will constitute sufficient scientific justification for high standards remains unclear. Under the subsidies agreement, however, the use of countervailing measures to deal with unfair trade practices in the form of lax environmental standards is not permitted. But the agreement does imply that subsidies that take the form of foregone revenue for environmental taxes can be countervailable if they are specific.

\footnotetext{
${ }^{12} \mathrm{~A}$ 'specific' subsidy is one considered only available to 'an enterprise or industry or group of enterprises or industries within the jurisdiction of the authority granting the subsidy', GATT (1994). The definition of a subsidy also rests on whether there is a financial contribution by a government or any public body.
} 


\section{Post Uruguay Round ${ }^{13}$}

At the ministerial meeting which concluded the Uruguay Round at Marrakesh in April 1994, the contracting parties agreed both that trade and environment should be on the future agenda for the WTO, and that a new Committee on Trade and the Environment (CTE) should be formed to assess trade and environment linkages. This Committee is to give its first report in Singapore in December 1996.

It was agreed that the agenda for the CTE work on trade and environment would cover (i) the relationship between multilateral environmental arrangements and the GATT/WTO, (ii) how environmental policies with significant trade effects impact the trading system (iii) how environmental taxes and charges interact with trade rules (iv) eco-labelling issues (v) WTO dispute settlement and MEAs (vi) environmental policy measures and market access and (vii) domestically prohibited goods. Progress on most of these issues has been slow. In essence, developed countries, and especially the EU, have argued for modifications to GATT/WTO disciplines for environmental reasons; while developing countries, fearful of legitimizing protection against their exports have taken a more cautious stance. Little of substance in any of these areas is expected to be concluded at Singapore.

On production and processing methods, proposals have been made to modify the present GATT principle of national treatment contained in Article III, and more specifically, the concept of like products, which presently disallows any distinction in trade policy treatment between products made in a clean' and 'dirty' manner. Present

\footnotetext{
${ }^{13}$ Also see the description of the wider post Unuguay Round agenda covering environmental and nonenvironmental issues in Woolcock (1996).
} 
GATT/WTO rules are seen as inconsistent with activist domestic environmental policies, since they inevitably imply a competitive disadvantage to domestic industries, if exporting countries have lower standards. On MEAs, the aim has been to secure a GATT/WTO accommodation of the trade provisions of their agreements before any GATT/WTO inconsistent measures are taken under the Montreal protocol. Proposals include expanding the scope of GATT Article XX exceptions to explicitly cover MEA trade measures; the granting of GATT/WTO Waivers for such trade measures; and the grant of limited (contained) waivers which would condition the use of MEA trade measures. On other less significant issues, accommodation may be possible; joint Codes of Conduct for eco-labelling schemes is one. But in general, the picture is one of limited movement on the trade and environment issues in the CTE agenda pre Singapore.

At a less technical level, however, trade and environment continues to be repeatedly cited as a major component of the likely future focus for global trade policy negotiation and debate. Renato Ruggiero, Director General of the WTO, has identified trade and environment as one of four issues (along with competitive policy, labour standards, and investment) which will shape the future work programme of the WTO, and eventually form the lead issues of a future multilateral negotiating Round. Immediately after the Uruguay Round, there were several calls for a new negotiating Round to be a 'Green Round', and such calls, while less frequent, are still heard.

This profile for trade and environment as a lead issue within GATT/WTO thus seemingly coexists with difficulties in making much progress in Singapore, and clear divisions between developed and developing countries on the issue. The trade and environment component of any future negotiation would also be a rule writing rather 
than traditional reciprocity based negotiation, and one with precedents for other potential rule writing exercises (such as labour standards). While the Uruguay Round established precedents for rule writing concessions (for instance, in Intellectual Property by the developing countries) it further complicates any leading role to be played by the issue in a future multilateral negotiating Round. 


\section{THE ENVIRONMENTAL AGENDA FOR GATT/NVTO AFTER SINGAPORE ${ }^{14}$}

Given both the limited concrete progress on the trade and environment issue that seems likely in Singapore and its likely continued high profile as a potential lead issue for a future negotiating Round, it seems useful to speculate how the debate on the issue may develop within the WTO after Singapore, out into the medium term. I would argue both that the technical problems and worries over precedent will complicate any accommodation within the WTO on the trade and environment issue and cleavage between developed and developing countries on trade and environment will be likely remain and even intensify after Singapore. Also, increasingly it will be the case that developments outside the GATT/WTO, such as the potential trade effects of new global environmental agreements, and, to a lesser extent, environmental arrangements concluded in regional agreements, will enter and drive the debate.

Thus, the talk of either a separate environmental negotiation - a 'Green Round' of negotiations, or an environment-lead new wider Round - talk that was heard even before the conclusion of the Uruguay Round, may well continue. The pressures which have been building for changes to be made within the GATT/WTO to accommodate environmental concerns may also remain as the focus for GATT/WTO debate on trade and environment after Singapore, but with growing frustration both from advocates and opponents of change. Concerns of environmental groups over what they see as secretive GATT/WTO processes, in which they have no rights to appear or appeal will persist. Linkage not only of GATT/WTO arrangements to multilateral environmental

\footnotetext{
${ }^{14}$ This section draws heavily on the discussion in Uimonen and Whalley (1996), Ch.6).
} 
agreements but also to new MEAs and onto trade patterns will become an evermore a key issue.

None of this indicates that nothing can be done in GATT/WTO post Singapore on trade and environment, as those who saw the seemingly deep divide on services pre Uruguay Round (in early 1986) will recall. But exactly how trade and environment would eventually be accommodated in GATT/WTO at this stage is unclear, both technically and politically; and what the GATT/WTO response would be, if there were one, to the wider impacts of environmental policies is at this stage unknown.

\section{Broad GATT/WTO Modification}

A variety of proposals have been offered as to how environmental considerations could be taken into account in future GATT/WTO agreements. One might be to more fully utilize what is presently available in the GATT, including the Article XXV waiver mechanism to allow for the use of otherwise GATT-inconsistent measures on evnironmental grounds. Another would be to seek changes to the GATT/WTO rules so as to allow for wide-ranging exceptions on environmental grounds. There could also be more narrowly focused elaborations and clarifications to the GATT agreements now in the WTO, aiming to deal centrally with environment and trade issues.

Waivers for individual Contracting Parties under Article XXV could be used for environmentally related trade restricting measures that would otherwise violate present GATT/WTO arrangements. Approval of a waiver requires a three-quarters majority..

- Environmental waivers could possibly take on more general forms than those which have been seen in the GATT thus far, which are usually narrowly focused and granted to only one Contracting Party at a time. There could be bloc waivers, given 
simultaneously to subgroups (or even all) Contracting Parties, and allowing them to use specific trade-restricting measures for environmental purposes. There could even be broad-ranging waivers setting out general conditions under which environmental exceptions would be allowed.

Waivers have the attraction of addressing environmental concerns while leaving the existing structure of GATT/WTO disciplines unchanged, thus avoiding any need for a potentially complex and divisive rule rewriting negotiation. However, a series of waivers granted on a case-by-case basis runs the risk of yielding a chaotic and inconsistent outcome. Each waiver request would have to go through a separate waiver approval process, repeatedly raising potential problems in reaching agreement. Also, more widespread use of waivers in the environmental area seems to go against the current GATT/WTO trend of downplaying the use of waivers in other areas (such as agriculture)

Another way to bring environmental considerations more fully into the GATT/WTO would be to directly amend the General Agreement to allow for more explicit environmental exceptions than it now contains, although the requirements are stringent. Some key GATT articles (including Articles I and III) require acceptance by all members, while others require a two-thirds majority. Furthermore, amendments must pass national treaty ratification procedures, which further reduces the potential for success.

Table 1 reproduces a list of the main GATT articles that could potentially be involved in such a negotiation given in Uimonen and Whalley (1996) ${ }^{15}$. The scope of the possible changes to the GATT/WTO is immediately striking. Central to any such

\footnotetext{
${ }^{15}$ See also Arden-Clarke (1991), and Patterson (1991)
} 
negotiation would be an attempt to clarify or change the language of $\mathrm{XX}(\mathrm{b})$ and $\mathrm{XX}(\mathrm{g})$. But other articles, including MFN and national treatment (Articles I and III) - the cornerstones of the GATT - might also be subjected to environmental review, as might a number of other key articles (VI, XI, XIII, XIV, XVI, XIX, XX) and trade provisions explicitly applying to developing countries (XVIII, and Part IV). Such a wide ranging negotiation on rule rewriting covering many GATT Articles would almost certainlyprove difficult to conclude, especially as many non environmental issues would likely be raised by individual countries. Alternatively, narrowing such a negotiation to only a few Articles makes it difficult to launch, because individual countries would want to see issues of particular importance to them dealt with.

An alternative but related approach might be to negotiate a side agreement on trade and the environment to so as to supplement and clarify the meaning of existing Articles of the General Agreement and other agreements in the WTO as they relate to environmental issues. For example, rules ranging from subsidy and competitiveness issues to procedures for the application of unilateral measures for environmental protection could be subject to clarification and elaboration. In addition, following GATT tradition since the Kennedy Round, 'special and differential treatment' on environmental issues could be granted to less-developed countries, perhaps in the form of longer time periods to implement environmentally related decisions. 
Potential Environmentally Motivated Changes in Selected GATT/WTO Articles"

\begin{tabular}{|c|c|c|}
\hline Article & Rule & Environmental Issues \\
\hline I. Most-Favoured-Nation & $\begin{array}{l}\text { The most favourable } \\
\text { treatment for exports and } \\
\text { imports must be granted to } \\
\text { 'like' products of all } \\
\text { countries. }\end{array}$ & $\begin{array}{l}\text { Distinguishing products on } \\
\text { the basis of environmental } \\
\text { impact of products and/or } \\
\text { PPMs. }\end{array}$ \\
\hline $\begin{array}{l}\text { II. Schedule of } \\
\text { Concessions }\end{array}$ & $\begin{array}{l}\text { Negotiated tariff bindings. } \\
\text { An exception to tariff } \\
\text { bindings allows for border tax } \\
\text { adjustments on imports } \\
\text { equivalent to domestic } \\
\text { charges on like products } \\
\text { consistent with Article III. }\end{array}$ & $\begin{array}{l}\text { Allow for border adjustments } \\
\text { on products using } \\
\text { environmentally damaging } \\
\text { PPMs. } \\
\text { Disallow adjustments when } \\
\text { imports have no cross-border } \\
\text { environmental effects. }\end{array}$ \\
\hline III. National Treatment & $\begin{array}{l}\text { Once they have cleared } \\
\text { customs and border } \\
\text { procedures, imported goods } \\
\text { are to be treated no less } \\
\text { favourably than like domestic } \\
\text { products with respect to } \\
\text { domestic taxes and } \\
\text { regulations. }\end{array}$ & $\begin{array}{l}\text { Distinguishing products on } \\
\text { basis of environmental impact } \\
\text { of products and/or PPMs. }\end{array}$ \\
\hline $\begin{array}{l}\text { VI. Anti-dumping and } \\
\text { Countervailing Duties }\end{array}$ & $\begin{array}{l}\text { Allow ADDs on imports } \\
\text { equal to the dumping margin } \\
\text { when there is material injury } \\
\text { as a result of dumping. } \\
\text { Allow CVDs on subsidized } \\
\text { imports when there is } \\
\text { material injury. }\end{array}$ & $\begin{array}{l}\text { Margins of dumping and } \\
\text { subsidy to include marginal } \\
\text { social costs of environmental } \\
\text { damage. } \\
\text { Countervailability of } \\
\text { pollution abatement subsidies, } \\
\text { "lax standard'subsidies. }\end{array}$ \\
\hline IX. Marks of Origin & $\begin{array}{l}\text { Provides for MFN with } \\
\text { regard to labelling } \\
\text { requirements; countries } \\
\text { should minimize adverse } \\
\text { trade effects of marks of } \\
\text { origin regulations. }\end{array}$ & $\begin{array}{l}\text { Treatment of 'ecolabelling' } \\
\text { laws. }\end{array}$ \\
\hline $\begin{array}{l}\text { X. Public and Administration } \\
\text { of Trade Regulations }\end{array}$ & $\begin{array}{l}\text { Countries should maximize } \\
\text { transparency of regulations } \\
\text { affecting trade. }\end{array}$ & $\begin{array}{l}\text { Extension of transparency } \\
\text { requirements to } \\
\text { environmental measures and } \\
\text { their scientific justification. }\end{array}$ \\
\hline XI. Quantitative Restrictions & $\begin{array}{l}\text { Prohibits quantitative } \\
\text { restraints on imports and } \\
\text { exports subject to certain } \\
\text { exceptions. }\end{array}$ & $\begin{array}{l}\text { Elaborate on or clarify } \\
\text { environmentally based } \\
\text { exceptions. }\end{array}$ \\
\hline $\begin{array}{l}\text { XII and XIV. Non- } \\
\text { discrimination in QRs and } \\
\text { exceptions }\end{array}$ & $\begin{array}{l}\text { Allowable QRs to be applied } \\
\text { similarly to all countries and } \\
\text { exceptions to this rule }\end{array}$ & $\begin{array}{l}\text { Allowable QRs to be applied } \\
\text { similarly to all countries and } \\
\text { exceptions to this rule }\end{array}$ \\
\hline
\end{tabular}

" This is reproduced here with slight modification from Table 6.01 in Uimonen and Whalley (1996) 


\begin{tabular}{|c|c|c|}
\hline XVI. Export Subsidies & $\begin{array}{l}\text { Export subsidies for primary } \\
\text { products should not result in } \\
\text { a more than equitable share of } \\
\text { world trade. } \\
\text { Conditional prohibition of } \\
\text { export subsidies to non- } \\
\text { prinary products. } \\
\text { Tokyo Round Code } \\
\text { prohibited these subsidies, } \\
\text { increased discipline on } \\
\text { domestic subsidies. } \\
\text { Uruguay Round prohibits } \\
\text { non-agricultural export } \\
\text { subsidies, further increases } \\
\text { disciplines on domestic } \\
\text { subsidies }\end{array}$ & $\begin{array}{l}\text { Further disciplines on } \\
\text { environmentally damaging } \\
\text { domestic subsidies. } \\
\text { Allowances for CVDs against } \\
\text { countries with 'lax'standards } \\
\text { on some margin reflecting } \\
\text { social cost. }\end{array}$ \\
\hline XVI. Border Adjustment & $\begin{array}{l}\text { Rebate of indirect taxes on } \\
\text { products or inputs contained } \\
\text { in products upon export is } \\
\text { permitted. } \\
\text { Uruguay Round allows for } \\
\text { rebate of indirect taxes on } \\
\text { enrgy used in production. }\end{array}$ & $\begin{array}{l}\text { Disallow rebates for } \\
\text { environmental taxes, energy } \\
\text { taxes on exported goods. }\end{array}$ \\
\hline $\begin{array}{l}\text { XVIII. Developing Country } \\
\text { Tariff Protection }\end{array}$ & $\begin{array}{l}\text { Allows developing countries } \\
\text { to give tariff and other } \\
\text { assistance for purpose of } \\
\text { economic development and to } \\
\text { improve standards of living. }\end{array}$ & $\begin{array}{l}\text { Allowances for } \\
\text { environmentally based } \\
\text { measures for developing } \\
\text { countries. }\end{array}$ \\
\hline XIX. Safeguards & $\begin{array}{l}\text { Allows countries to take } \\
\text { othenvise GATT-inconsistent } \\
\text { measures temporarily when } \\
\text { imports harm a competing } \\
\text { domestic industry. }\end{array}$ & $\begin{array}{l}\text { Allowances for trade } \\
\text { measures to deal with sudden } \\
\text { environmental problems } \\
\text { associated with imports or } \\
\text { exports. }\end{array}$ \\
\hline XX. General Exceptions & $\begin{array}{l}\text { Allows measures 'necessary' } \\
\text { for protection of health and } \\
\text { safety 'relating to' protection } \\
\text { of exhaustible natural } \\
\text { resources. }\end{array}$ & $\begin{array}{l}\text { Loosening of 'necessity' test. } \\
\text { Allowances for second-best } \\
\text { measures. Allowances for } \\
\text { extra-jurisdictional } \\
\text { application of measures. } \\
\text { Allowances for sanctions. }\end{array}$ \\
\hline $\begin{array}{l}\text { XXIV. Free Trade Areas and } \\
\text { Customs Unions }\end{array}$ & $\begin{array}{l}\text { Criteria for regional trading } \\
\text { arrangements to be GATT- } \\
\text { consistent. }\end{array}$ & $\begin{array}{l}\text { Require EIAs in evaluating } \\
\text { RTAs and consistency of } \\
\text { environmentally related } \\
\text { provisions of such } \\
\text { agreements. }\end{array}$ \\
\hline
\end{tabular}

"This is reproduced here with slight modification from Table 6.01 in Uimonen and Whalley (1996) 


\begin{tabular}{|l|l|l|}
\hline Part IV. Special and & Exceptions or easements for \\
Differential Treatment & developing countries from \\
any new environmental & disciplines. Exceptions for \\
& & developing countries to allow \\
& for othenvise GATT- \\
& inconsistent measures related \\
& to environmental protection. \\
\hline
\end{tabular}

- This is reproduced here with slight modification from Table 6.01 in Uimonen and Whalley (1996) 
However, in the short run, it seems likely that the only practical mechanism available for fundamental environmental rule modification in the GATT/WTO fundamentally will be waivers, and these seem likely to yield an unsatisfactory conclusion. Even over a longer period, it remains unlikely that the GATT/WTO would be fundamentally amended, given both the scope of change and the practical difficulties involved. If, at some future date, the Contracting Parties attempt to agree on new trade/environment rules, it would most likely be in the form of a side agreement supplementing and interpreting existing rules.

\section{Article XX Reform}

At the forefront of any effort to change GATT rules as they apply to the environment would be both clarification and reconsideration of Article XX exceptions ${ }^{16}$. The issue here is as much one of determining what the current rules actually imply, as it is one of changing existing rules.

There is currently substantial confusion about the precise meaning of Article XX exceptions. Previous Article XX panels appear to have reached a consensus, that measures must be 'necessary' for health and safety or 'primarily aimed at' the conservation of an exhaustible resource. But confusion remains over whether exceptions should be narrowly defined to prevent their abuse, and the justification for such a narrow definition. For instance, the first ${ }^{17}$ tuna-dolphin panel restricted the scope of Article XX by limiting its jurisdictional application. The second panel - backtracked from the first panel on this point, and it substituted a criterion whereby a

\footnotetext{
${ }^{16}$ See the extensive discussion of Article XX issues in Charnovitz (1992), and Esty (1994, Ch.9)..

${ }^{17}$ See the earlier discussion in footnote 8, p.8, on the two tuna-dolphin panels.
} 
country could not impose trade restrictions for environmental or other reasons, if the only way it could achieve its objective was by forcing the affected country to change its domestic policies

There have been proposals for wide-ranging amendments to Article XX, to the effect that nothing in the GATT/WTO would prevent any Contracting Party from taking any action 'which it may deem necessary to protect the environment, including the establishment of import or export restrictions, and the use of subsidies ...' (Shrybman, 1989). These have been linked to provisions that, in any GATT/WTO dispute regarding actions taken to protect the environment (domestic or otherwise) the onus should be on the complainant to prove that the measure 'was not taken in good faith and that it was unreasonable' (Shrybman, 1989) ${ }^{18}$. A precedent for such proposals appears to be GATT Article XX(h) which provides exemptions for signatories to international commodity agreements along related lines. The obvious weakness is that such exemptions would provide open-ended cover for protection, as well as promote inefficient environmental policy. Under the cover of such an exemption any trade actions could, in principle, be taken in the name of environmental concerns ${ }^{19}$. Because of this, opposition to such proposals is especially strong, particularly from developing countries.

Trade restrictions on products with PPMs that cause environmental damage in the importing country are also an Article XX issue (as well as an Article III (MFN) issue) since they were called into question in the second tuna-dolphin panel report. The panel - report asserted that the trade restrictions at issue could not, by themselves, achieve their

\footnotetext{
${ }^{18}$ Similar proposals for broad-ranging exceptions from GATT obligations for environmental purposes may be found in Arden-Clarke (1991).

${ }^{19}$ This obviously raises the political economy issues discussed in Hillmand and Ursprung (1994).
} 
environmental objective; and so, if allowance is to be made for such second-best policies, the circumstances under which they would be permitted need to be addressed. This raises once again the issues implicit in the tuna-dolphin panel reports concerning 'necessity' tests; whether extrajurisdictional measures should be disciplined more severely, and how measures taken in the context of international environmental agreements should be dealt with.

One possible change might be to permit trade measures for extrajurisdictional environmental protection, but require that they be 'necessary' in a stricter sense than for measures to protect domestic health, safety, or environment. Such additional criteria might include demonstration of prior attempts to negotiate an international agreement under the auspices of an agreed upon international body, such as UNEP; and a 'good faith' estimate and offer of resource transfers, or even trade compensation.

Future reconsideration of the use of trade measures under Article XX may also draw on the results of UNCED, which reiterated the need to avoid arbitrary discrimination and disguised trading barriers, as with existing GATT rules. The Rio Declaration called on countries to avoid unilateral attempts to address environmental problems which originate outside a country's territorial jurisdiction. Furthermore, it called on countries to base their solutions on international consensus as far as possible.

If there is a general approach to rewriting Article $X X$ so as to clarify general exceptions from GATT/WTO disciplines for environmental trade measures emerging from these documents, it is to avoid unilateralism and new forms of protectionism as far - as possible. However, there is widespread disagreement as to exactly how to circumscribe future allowances for environmentally motivated trade measures in elaborating on these general principles. 


\section{Environmental Regulation}

An equally central GATT/WTO issue beyond Singapore will be the interaction of environmental regulation and trade policy. The national treatment obligation under GATT/WTO in Article III requires Contracting Parties not use internal taxes or regulations in ways which give domestic protection, and requires domestic policies to treat imports no less favourably than 'like' domestic products. The GATT has interpreted this provision as requiring Contracting Parties not to use measures to discriminate in favour of products. The concept of 'like' product has been widely interpreted as prohibiting trade restrictions based on the processes and methods (PPMs) used to produce imported goods. PPM-based trade restrictions become prima facie violations of national treatment, which then must be justified under Article $\mathrm{XX}$ if they are to be allowed.

There are a variety of ways in which these disciplines might be relaxed. One approach might be to allow any measures which do not violate MFN and national treatment obligations. This would clearly be inadequate to discipline the protectionist use of such measures. Another might be to change the wording in Article $\mathrm{XX}(\mathrm{b})$ from 'necessary' to 'relating to' as in Article $\mathrm{XX}(\mathrm{g})$, with the aim of weakening the requirement that has evolved in past panel disputes, that a measure must be the least GATT-inconsistent measure reasonably available ${ }^{20}$. New language might require measures to be 'consistent with, and a part of, the framework of environmental policies of the nation imposing the measure' (Patterson, 1992, 107). Thus, rather than - considering trade-restrictive measures within the set of all possible policies to achieve a given objective with a view toward identifying a less GATT-inconsistent measure, this

\footnotetext{
${ }^{20}$ See Patterson (1992).
} 
approach might allow trade-distorting measures related to a nation's domestic environmental policies, as long as they avoid (in some sense) in protectionist abuse.

Dispute settlement panels have already examined whether regulatory or tax distinctions used for non-trade objectives are allowable in determining whether 'like' products are treated in accordance with Article III. The task for the WTO dispute settlement process on these matters has been to walk a line restricting national policymaking that inevitably entails incidental trade effects, and permitting the use of ostensibly domestic taxes and regulations for protectionist purposes.

Even if domestic taxes or regulations violate the national treatment obligation under Article III, they may still be justified under Article XX This will raise further questions post Singapore as to how stringent such exceptions might be. The GATT approach to trade measures taken to protect domestic health, safety and environment under Article $\mathrm{XX}(\mathrm{b})$ thus far has been to permit them as long as they can be shown to be 'necessary' for the purpose, i.e. that they are the least GATT-inconsistent, or tradedistorting, measures available. For example, the Uruguay Round discisions discipline standards that are more stringent than international norms, to ensure that they are the 'least trade-distortionary' measures available. Whether this approach prevails will be an issue.

\section{Transparency}

Concerns have been frequently expressed in the environmental community over the - seemingly closed procedures used in GATT/WTO negotiations and dispute settlement of environmental cases. These issues seem likely to persist post Singapore ${ }^{21}$. The most

\footnotetext{
${ }^{21}$ See also Arden-Clarke (1991) and Jackson (1992).
} 
significant concerns have focused on the seeming secrecy of the dispute settlement process since most domestic legal systems define rights to appear before administrative tribunals, and also give rights to interested parties to appeal decisions. The absence of such rights in GATT disputes involving environmental issues has concerned many environmentalists.

The response from the trade community is usually to argue first, that panel procedures represent efforts to depoliticise political conflicts involving national governments, and that a more open process would undermine these efforts. They argue, second, that if such rights are granted to environmental groups, similar rights would have to be granted to other political groups in both environmental and other cases, potentially derailing the process.

Another transparency issue involves the provision of information to judge the environmental effects of proposed policy changes, including the outcome of any future multilateral negotiation.. In the US, federal policies often require environmental impact statements (EISs), under the 1969 National Environmental Policy Act. An unsuccessful attempt was made in the US courts to force compliance with this act arguing that the NAFTA and Uruguay Round agreements should be subject to its requirements. While there may be justification for assessments where narrowly focused trade policy changes with a significant environmental link are at issue, a requirement for entire trade agreements where most elements have no direct environmental relationship immediately apparent, runs the risk of significantly complicating the negotiation and ratification processes.

While an open process for trade negotiations, such as the Uruguay Round, may make exchanges of concessions more difficult, a more transparent set of procedures for 
dispute settlement would seem to be an improvement, especially for disputes arising over the trade effects of domestic policies, such as those under the S\&P and TBT agreements. Under these agreements, either party to a dispute can request the formation of a technical expert group to examine the scientific merits of standards that appear stricter than international norms. The work of the expert group is then used by the panel; such panels may, but are not required to, seek information from outside sources. Some have suggested that a special category of cases be established for environmentally-related disputes, before which expert opinion can also be placed.

\section{Subsidies and Competitiveness Issues}

Questions will also arise post Singapore about the relationship between to environment, subsidies and competitiveness. These include whether to change current trade rules that restrict export and domestic subsidies, even if used for environmental protection; whether relatively lower environmental standards should be countervailable; and whether trade discipline on the use of subsidies might be environmentally beneficial.

The Uruguay Round increased restraints on the use of export subsidies, and these new rules apply equally to pollution abatement and other non-primary product industries. The idea behind limiting the use of export subsidies is to both prevent an 'unfair' trade advantage accruing to exporters receiving such subsidies, and to achieve neutrality with respect to trade policies (i.e., tariffs and export subsidies).

Export subsidies for environmentally friendly products are seen as a mechanism

- through which environmental protection technology could be transferred to developing countries, even though cash transfers to developing countries adopting appropriate environmental policies and not tied to purchase of particular products, would be more 
efficient. However, there is a general reluctance to allow the use of such subsidies in light of experience in agriculture where subsidy wars have occurred. Furthermore, if not carefully designed, such special exceptions for export subsidies could lead to incentives to adopt end-of-pipe clean-up technologies as opposed to products and processes that pollute less and are inherently cleaner. Also, any use of such subsidies should be approached with caution because they can stimulate entry into polluting industries. Allowance for domestic environmental subsidies not 'generally available' would also need to be carefully designed to prevent abuse.

Thus, while environmental allowances for export and domestic subsidies will likely be explored post Singapore, particularly with respect to increasing access for lessdeveloped countries to environmental protection technology, this will probably be done cautiously so that incentives to use subsidies (as opposed to 'polluter-pays' policies) do not grow.

\section{Other GATT Articles}

Post Singapore there will also likely be a discussion of environmental issues with other GATT Articles outside of Article XX. Table I earlier gives a list of GATT articles which could potentially come under scrutiny in any attempt to rewrite the GATT/WTO in the light of environmental concerns.

Articles I and III, the non-discrimination and national treatment cornerstones of the GATT, could be an initial focal point for such efforts. The objective would be that they be modified so as to allow discriminatory trade actions on environmental grounds. While Article XX is the natural route for countries seeking to use such measures, this will likely not preclude such changes being sought in the future. Under Article IX, 
various ecolabelling issues such as those implied by recent EU policy may be raised. At issue is the extent to which such measures represent non-transparent trade discrimination, or impose added costs on foreign producers.

Possible issues with Articles XI and XIII could be discriminatory import bans similar to those under dispute in the tuna-dolphin case. Pressures could be exerted here for special environmental exceptions to these two Articles, without the need to argue cases under the general exceptions of Article XX.

Article XVIII, which implies less stringent discipline on less-developed countries' use of tariffs and trade restrictions either to promote infant industries or for balance-ofpayments reasons, could be a further focal point. Arguments could be made here either to grant further special rights to developing countries to allow use of trade restrictions which are, in some way, environmentally enhancing. Alternatively, existing special provisions could be restricted to make them conditional on the environment impacts of the policies used.

With Article XIX, which deals with safeguards, (circumstances under which countries can use trade-restricting measures to deal with import surges into their markets), an argument that has surfaced is the need for special rules to deal with surges from countries with environmentally lax standards or to deal with imports of products from areas of recently determined environmental damage. A requirement for environmental impact statements to be added into Article XXIV, which deals with free trade areas, is one possible direction that discussion could take.

Finally, Part IV of the GATT (Articles XXVV-XXXVIII), which both details the special and differential treatment developing countries are to receive in the trading system, could still be an important element in a future trade and environment 
negotiation, because of the basic commitment it gives to developing countries to open trade and, hence, compensation for environmental restraint.

\section{Environment in a New Trade Round}

As noted above, we are still some considerable way from the launch of a new trade round in the WTO, and some have even suggested that with ongoing 2-yearly ministerial meetings, a form of permanent negotiation might replace the GATT Rounds of the past. As I have indicated in a recent piece with Colleen Hamilton (Whalley and Hamilton, 1996), I would see this as unlikely for a number of reasons; deadlines to terminate force decisions; initial agenda forming negotiations define the bargaining set; and they also focus the reciprocal dealing to follow. Also, the 10-year implementation period for the Uruguay Round makes the launch of a new Round quickly unlikely. Nonethelesss, even for Singapore there have been calls for a commitment to be made to Global Free Trade by 2015 to lead the way to new multilateral negotiations to counterbalance regional initiatives such as APEC and FTAA.

Where then does trade and environment fit into all this? I suggested above that trade and environment seemingly is in the odd position of having enormous political momentum behind it as a lead issue for a future negotiation, while at technical and negotiating level seemingly being boxed in by problems of precedent and difficulties of counteracting the intent of established trade rules. These problems are greatly compounded by the North-South divide which seems to face any proposed significant change in the area.

Trade and environment will in my view remain a lead symbolic issue to the WTO work programme, but several developments could serve to slowly downplay its 
significance in a future Round. One would be a future Round more heavily focused on traditional reciprocity than rule writing (exchanges of concessions involving the new (post Uruguay Round) tariffs in agriculture, post MFA elimination tariffs in apparel, bound tariffs in developing countries). Another would be fragmentation of the current four "new-new",22 key issues of environment, labour standards, competition policy and investment into separate negotiating boxes, which could happen with competition policy and investment. Yet another would be the continued non emergence of an issue on which developing countries could be given something in return for concessions by them on environment.

Thus, the post Singapore scenario I see is a continued high political profile for the trade and environment issue in the GATT/WTO, but with little substantive agreement either before or during a subsequent negotiating Round.

${ }^{22}$ In contrast to the "new" issues in the Uruguay Round of services, TRIPs and TRIMs. 


\section{WIDER DIMENSIONS OF TRADE AND ENVIRONMENT LINKAGE POST SINGAPORE}

Because of the arguments I make above regarding the prospects for progress post Singapore in the GATT/WTO on future trade and environment linkage, it should be no surprise that I also argue that the way that the trade and environment issue evolves post Singapore will reflect a range of factors beyond the technicalities of the GATT. These include the likely quantitative importance of what is at stake, the political divisions the issue creates and environmental provisions of regional trade arrangements (not discussed here in any detail) ${ }^{23}$.

\section{Implications of Quantification of Trade and Environment Linkages ${ }^{2-1}$}

The preliminary indications now beginning to emerge from model based quantitative analyses of trade and environment interactions is that those that have been the subject of most debate and discussion in the GATT and other fora thus far may be of largely symbolic importance, with only limited consequences for global economic performance. On the other hand, the trade consequences of major environmental interventions not yet figuring prominently in the trade and environment debate, such as those that would follow from a possible global carbon tax, could seemingly be more substantial. In an extreme case, they might even reverse the growth in world trade in manufactures that we have seen in the last four decades of GATT-based trade liberalization. These studies typically involve calibration of models to various

\footnotetext{
${ }^{23}$ However, see the discussion in Esty (1994) and in Uimonen and Whalley (1996).

${ }^{24}$ This subsection draws on the discussion in Whalley (1996b).
} 
benchmark or base case data sets, followed by counterfactual analysis around base cases.

One study suggesting small effects from those trade and environment policy linkages discussed thus far is Perroni and Wigle (1994) whose model covers six goods and sectors chosen to allow a separation between industries with more emissions and those with less, and to also allow separation of higher technology from lower technology industries. They calibrate their model to a 1986 global data set covering 3 major regions, North America, Other Developed and Low and Middle Income countries), and a variety of pollutant activities. Emissions generated by industrial activity interact with various natural and geographical processes, including absorption and transmission of particulates via the atmosphere and oceans, impacting global environmental standards, and hence environmental quality for consumers. Having calibrated their model to a 1986 benchmark data set, Perroni and Wigle are able to analyze the effects of increased trade on environmental quality by alternative trade policy scenarios, including removal of all global trade barriers in their model. They directly capture the welfare effects of changes in environmental standards in the form of damage functions in explicit utility evaluations.

Their model results suggest that increased international trade generally has little impact on environmental quality. They also conclude that the magnitude of welfare effects of environmental policies are not significantly affected by simultaneous changes in trade policies when new environmental policies are introduced. Furthermore, the size - and regional distribution of the gains from trade liberalization appears to be little affected by environmental policies. Their tentative conclusion is that the extent of trade 
and environment interactions seem smaller than might have beeen suggested by the intensity of debate on trade and environment up to the time of their writing (1993).

Another model based piece examining more conventional trade and environment linkages is Low (1992), which attracted substantial attention when published because of the similar conclusion that the trade impacts of environmentally oriented trade policies seem small ${ }^{25}$. Low reports a model based calculation of the effects of possible trade barriers being adopted in the United States to countervail perceived lax standards in key trading partners, including Mexico, and reports their impacts on trade. He uses data on pollution abatement costs by type of expenditure and by sector for the United States, which are, in turn, used to infer at what level trade barriers could be introduced in the US to counteract competitive disadvantages under an assumption of zero costs being incurred by firms in Mexico. The effects of such trade barriers on trade are then analyzed, using a model structure which captures relevant demand and supply elasticities.

Low identifies pollution intensive, or 'dirty' industries, as those with the highest pollution abatement expenditures. These industries are evaluated as to their contribution to Mexico's exports, and a simulation used to assess the effects on the exports of a special US import tax along the lines outlined above. In Low's data, such expenditures currently represented only a small part of total costs incurred by US

\footnotetext{
${ }^{25}$ Low's conclusion is also consistent with that reached by Tobey (1990) who uses an econometric approach to test the significance of pollution effects in a Heksher-Ohlin-Vanek model. A commodity's relative pollution intensity is defined in terms of pollution abatement costs incurred in production compared to similar US data, with endowment data from Leamer (1984), and trade data from UN trade statistics. Tobey's conclusion is that stringent environmental regulations imposed on industries in the late 1960 s and early 1970 s by most industrial countries have not affected trade patterns to any measurable extent in the most heavily polluting industries. A more recent piece by Levinsohn (1994) concludes that differing environmental regulations across states have little effect on location decisions; in part because, once again, the cost shares involved are small.
} 
industries, with only 18 out of 123 industries incurring more than $1 \%$ of the value of their output in pollution abatement costs. On this basis alone, the impact of a special import tax, while still dependent on assumed values of elasticities, would thus be likely to be small.

Using a simple elasticity-based approach and 1986 data, Low's results suggest that the imposition of such a tax would cause a reduction of less than $2 \%$ in Mexico's exports. This compares with an approximate doubling in real terms for Mexico's trade with the United States between 1985 and 1992, suggesting that, if actually implemented, such environmentally based trade measures would have only a small effect on direct trade flows, because the cost components involved are themselves small.

However, a further set of model based analyses, analyzing the effects of major global environmental initiatives due to Whalley and Wigle (1991) and Piggott, Whalley and Wigle (1993) in two interrelated modelling papers, suggest that much larger trade effects would follow from new global arrangements designed to deal with major environmental problems, such as carbon emissions. The purpose of these two papers is to analyze the effects such as a possible carbon tax set at levels designed to stabilize global carbon emissions at early 1990s levels (the so-called 'Toronto call', after the setting of such an objective at a 1989 global scientific conference in Toronto) ${ }^{26}$. In both models, there is a production and demand structure in each region, with CES production functions defined over primary factors and other inputs. Primary factors, in - turn, are broken down into energy and non-energy inputs, which cover greenhouse and

\footnotetext{
${ }^{26}$ Also see the recent renewed call for stringent emission targets by the International Panel on Climate Change (IPRC); "Tough Targets on Greenhouse Gases Urged", Financial Times, Friday 19th July 1996.
} 
non-greenhouse, and carbon and non-carbon products. This leads to production of composite energy and, in turn, the eventual production of energy intensive and nonenergy intensive products. International trade then takes place in energy-intensive and other goods, and carbon based products.

In the first piece, the possible international impacts of carbon tax options are evaluated. In the second the extent of sub-regional or unilateral country reduction in carbon emissions which would be undertaken to deal with global warming are analyzed, using a model extension with an explicit parameterization of preferences towards climate change. Results from these models suggest large effects on international trade flows from major environmental policy interventions, such as a carbon tax. The published papers do not directly report trade impacts since this was not their major focus, but in the presence of large carbon taxes which apply to a significant input component for manufacturing (and where the tax rates required range as high as $800 \%$ in order to generate reductions in carbon emissions to stabilize globally at 1990 levels) the cost component feeding through to manufactures is large. The result is a potentially major impact on international trade in manufactures, and resulting changes in global trade patterns. Global consumption of energy intensive manufactures falls sharply, and with it global trade. Some model scenarios suggest that taxes at such high levels as these could have more major consequences for trade in the global economy as developments under GATT the post-war years.

Thus, for example, in Whalley and Wigle (1991) there are major changes in net - trade patterns between energy intensive goods and other goods for major regions. Japan, for instance, changes from net exporter of energy intensive manufacturers to a net importer. Other Europe, including eastern Europe, changes from a net importer to 
a net exporter, and the EU also changes from a net exporter to a net importer. In some results in Piggott, Whalley and Wigle (1993, p.127) there are further reductions in trade in the order of $50 \%$ from large global carbon taxes

The implication is that major environmental policy initiatives in the post Singapore trading system may have more significant impacts on trade pattern, than initiatives undertaken within the GATT/WTO framework to more directly address the trade and environment issue. The GATT/WTO has little to say about such initiatives, and yet their implications for trade could overwhelm the trade impacts of anything done directly in the WTO on the trade and environment issue. While a carbon agreement may still be some years (or even decades) away, its significance for the trade and environment debate seems clear.

\section{Developing Countries, Property Rights and Trade and Environment}

A further important factor to take into account in charting the future of the trade and environment debate post Singapore involves the developing countries, who see linkage of trade to environmental quality as being driven largely by environmental interests in the higher rather than the lower income countries. ${ }^{27}$ Their implicit argument is that environmental quality is a luxury good, and see consumer preferences of the higher income countries, not the lower income countries, as behind proposed rules linking trade and environment. From their perspective, these rules largely involve threats of trade restrictions being placed on their exports to pressure them to change - their environmental policies, while richer industrialized countries seem not to be

\footnotetext{
${ }^{27}$ See the more extensive discussion of the developing country position on these issues in Whalley (1994)
} 
targeted. The outcome they fear is that their growth and development is truncated by policies targeted at environmental conservation objectives set for their economies from outside. Developing countries, therefore, talk of 'green' or 'eco' imperialism, arguing that if the trading system continues to develop in this way, in the long run it can only be disadvantageous to them.

The tension is between the objectives of environmental advocates in industrial countries, and the strongly stated interest of developing countries in being able to pursue trade-led developmental strategies free from trade restrictions, including those motivated by environmental concerns. The developing countries also emphasize the extensive unilateral liberalization that has taken place in the developing world in the late 1980s and early 1990s, the trade gains which have flowed from this, and the industrial countries who have strongly supported it. Trade restrictions against developing countries in the name of environmental concerns of the wealthy in the developed world seem, to developing countries, to run counter to what they have been encouraged to do in recent years within the trading system.

Developing countries thus argue their property rights as far as any future trade and environment linkage is concerned. On issues such as deforestation, ${ }^{28}$ they argue that the developed countries industrialized two hundred years ago and largely deforested during the process. They question the grounds on which the developed countries now assert rights over management of forests in developing countries, when their own deforestation was so clearly unrestrained in earlier years. Some developing countries - go even further and argue that they should be compensated for showing environmental

\footnotetext{
${ }^{28}$ See Barbier et al. (1991) who analyze the environmental implications of trade in forestry products.
} 
restraint, rather than being penalized if they fail to adopt environmental policies advocated by industrial countries.

These issues were strongly in evidence at the 'Earth Summit' in 1993 at Rio de Janiero. The Summit was held as part of the United Nations Conference on Environment and Development (UNDED), and the North-South tensions over the property rights issues discussed above were clearly evident. Three agreements resulted from the Rio meeting; the Rio Declaration on Environment and Development; Agenda 21; and the Forest Principles. Two further agreements were separately negotiated but signed at Rio; the UN Framework Convention on Climate Change, and the UN Convention on Biological Diversity.

The Rio Declaration states (in Principle 12) that trade policy measures used for environmental purposes should not involve arbitrary discrimination or be disguised trade restrictions, and that unilateral actions should be avoided. Chapter 2 of Agenda 21 stresses that all countries should benefit from an open trading system. While in no way representing binding and enforceable commitments, these statements nonetheless add political support to developing country positions on trade and environment issues, and threaten to fuel whatever post Singapore divisions emerge on the issue.

Post-Singapore, trade and environment is also one of several elements of trade policy linkage to non trade objectives which threatens to revive North-South tensions in the trading system (trade and labour standards is another). These were pronounced in the 1970s and early 1980s, but began to ebb in the mid 1980s when many developing countries abandoned import substitution protection, liberalised unilaterally, and then participated much more actively than before in the Unguay Round. Having been assured that the trading system would be structured to speed their growth and 
development, finding in the mid 1990s that trade barriers against them may go up because of environmental concerns can only serve to unify developing countries in a rediscovered common cause. After moving away from the perceived blocwide interest of special and differential treatment towards pursuit of country interest, trade and environment post Singapore could well be the key to reviving the pursuit of a common Southern interest.

The trade and environment issue is thus seen by several developing countries in negative, and even hostile, terms. To them environmental pressure groups in wealthy countries in the developed world want to set global standards for environmental quality which meet their preferences, not those of the developing world. The ability of developing countries to provide environmental quality at these levels, and in ways which do not jeopardize their ability to achieve growth and development, is the issue.

Their rallying $\mathrm{cry}$ is one of compensation for environmental restraint, rather than legimitization of trade-based retaliation against environmental practices through trade rules. If developed countries are concerned about forest cover, they have the option of replanting trees in their own countries which they deforested centuries earlier even though to the more vocal environmental groups in developed countries such trees represent the lungs of the earth, a communally owned resource to be managed on a global basis. Developing countries thus see a policy agenda emerging in the developed world in which trade and environment plays a major role which seeks to define the parameters of a global resource management regime, independently of their growth and development aspirations. 


\section{CONCLUSIONS}

This paper seeks to map out how the trade and environment issue may play out after the Singapore WTO ministerial meeting in December 1996, where the WTO Committee on Trade and Environment (CTE) is scheduled to offer its first report.

The paper first discusses trade and environment narrowly as a GATT/WTO issue arguing both that relatively little is expected to be concluded in Singapore, and that change post Singapore looks equally difficult to achieve. All ways forward to change; waivers, general GATT/WTO exceptions, rewriting GATT Articles, seem to encounter problems.

The paper then argues that wider developments outside GATT/WTO are likely to prove equally if not more important to the future evolution of the trade and environment issue. These include the trade impacts of new major environmental arrangements, such as global carbon taxes; and the hardening position on these issues in the developing world. When taken together with other factors, such as the environmental provisions of regional trade agreements, the post Singapore prospects for trade and environment seem likely to be shaped as much by developments outside the GATT/WTO as within it. 


\section{BIBLIOGRAPHY}

ANDERSON, K. and R. BLACKHURST (eds.)(1993). The Greening of World Trade Issues, Harvester Wheatsheaf for the GATT.

ARDEN-CLARKE, C. (1991). The General Agreement on Tariffs and Trade, Environmental Protection and Sustainable DevelopmentI. World Wildlife Fund Discussion Paper.

BARBIER, E., B. AYLWARD, J. BURGESS and J. BISHOP (1991).

"Environmental Effects of Trade in the Forestry Sector". International Institute for Environment and Development: London, mimeo.

BEGHIN, J.D., R. HOLST and D. VAN-DER-MENSBRUGGHE (1994). "A Survey of the Trade and Environment Nexus: Global Dimensions". OECD Economic Studies, Winter, pp.167-92.

BHAGWATI, J. (1993). "Trade and the Environment: The False Conflict"in Zaelke, D., P. Orbach, and R. Houseman (eds), Trade and the Environment, Lonw, Economics, and Policy. Washington: Island Press.

CHARNOVITZ, S.(1992). "GATT and the Environment: Examining the issues". International Environmental Affairs, Vol.4, No.3, pp.203-33.

CHARNOVITZ, S. (1991). "Exploring the Environmental Exceptions in GATT Article XX". Journal of World Trade, Vol 25, No.5, pp.37-55.

COPELAND, B.R.and M. SCOTT-TAYLOR (1995). "Trade and Transboundary Pollution". American Economic Review, Vol.85, No.4., pp.716-937.

COPELAND, B.R. and M. SCOTT TAYLOR (1994). "North South and the Environment". Quarterly Journal of Economics, Vol.109, No.3, pp.755-87.

DEAN, J.M. (1992). "Trade and the Environment: A Survey of the Literature", in Low and Patrick (eds,), International Trade and the Environment. World Bank Discussion Papers, No.159: Washington: DC

ESTY, D.C. (1994). Greening the GATT: Trade, Environment, and the Future. Washington: Institute for International Economics.

GATT (1994). The Final Act of the Unugucry Round. Marrakesh, 1994.

- GATT (1992a). "Trade and the Environment" in International Trade 90-91. Vol. I (Part III). Geneva: GATT.

GATT (1992b). Focus 9J. Geneva. 
HILLMANN, A. and H. URSPRUNG (1994). "Greens, Supergreens, and International Trade Policy: Environmental Concerns and Protectionism", in Trade, Innovation and Environment. Dordrecht: Kluwer Academic Publishers.

JACKSON, J. (1992). "World Trade Rules and Environmental Policies: Congruence or Conflict?". Washington and Lee Law Review, Vol.49, No.4, Fall.

LEAMER, E. (1984). Sources of International Comparative Advantage: Theory and Evidence. Cambridge: Cambridge University Press.

LEONARD, R. and E. CHRISTENSEN (1991). "Testimony on Behalf of the Community Nutrition Institute Before the International Trade Commission Hearing on Economic Effects of a Free Trade Agreement Between Mexico and the United States". April 12, 1991.

LEVINSOHN, A. (1994). "Environmental Regulations and Manufacturer's Location Choices: Systematic Evidence from the Census of Manufactures", mimeo, presented at the Transatlantic Public Economics Conference on Market Failures and Public Policy, Turin, May 19-21, 1994.

LOW, P. (1992). "Trade Measures and Environmental Quality: The Implications for Mexico's Exports", P. Low (ed.), International Trade and Environment. World Bank Discussion Paper 159. The World Bank: Washington, D.C. 105-120.

PATTERSON, E. (1992). "GATT and the Environment- Rules Changes to Minimize Adverse Trade and Environmental Effects". Journal of World Trade, Vol.26, No.8, June, pp.99-109.

PERRONI, C. and R. WIGLE (1994). "International Trade and Environment Quality: How Important are the Linkages?". Canadian Journal of Economics, Vol.27, No.3, pp.551-67.

PIGGOTT, J., J.WHALLEY, and R.WIGLE (1993). "How Large are the Incentives to Join Sub Global Carbon Reduction Initiatives?". Journal of Policy Modelling, September.

RUNGE, C.F. (1994). Freer Trade, Protected Environment. Balancing Trade Liberalization and Environmental Interests. New York: Council of Foreign Relations Press.

SHRYBMAN, S. (1989). International Trade and the Environment. Toronto: Canadian Environmental Law Association.

SHRYBMAN, S. (1990). International Trade and the Environment: An Environmental Assessment of Present GATT Negotiations. Toronto: Canadian Environmental Law Association.

UTMONEN, P. (1995). "Trade Rules and Environmental Controversies". The World Economy, Vol.118, No.1, January, pp.71-86. 
UIMONEN, P. and J. WHALLEY (1996). The Trade and Enviromment Issue After the Uruguay Road Macmillan: xxxx.

ULPH, A. (1994). "Environmental Policy and International Trade: A Survey of Recent Economic Analysis". Noti di Lavoro 53.94. Milan: Foundazione Eni Enrico Mattei.

TOBEY, J.A. (1990). “The Effects of Domestic Environmental Policies on Patterns of World Trade". Kyklos, Vol.43.

WHALLEY, J. (1996a). "Trade and environment, the WTO and Developing Countries", in R. Lawrence (ed), Emerging New Issues in Global Trade. Overseas Development Council: Washington, DC.

WHALLEY, J. (1996b). "Quantifying Trade and Environment Linkages Through Economywide Modeling:. In M.E. Bredahl, N. Ballenger, J.C. Dunmore and J.L. Roe (eds.), Agriculture, Trade, and the Environment Westview Press: Colorado.

WHALLEY, J. (1994). "Compensation or Retaliation: Developed and Developing Countries and the Growing Conflict Over Global Environmental Conservation", Institute for Policy Reform, May 1994.

WHALLEY, J. (1991). "The Interface Between Environmental and Trade Policies". Economic Jommal, Vol. 01, No 405, 180-189.

WHALLEY, J. and C. HAMILTON (1996). The Trading System After the Uruguay Round. Washington: Institute for International Economics.

WHALLEY, J. and R. WIGLE (1991). "The International Incidence of Carbon Taxes", in R. Dornbusch and J.M. Poterba (eds.) Economic Policy Responses to Global Warming. Cambridge, USA:MIT Press.

WOOLCOCK, S. (1996). "An Agenda for the WTO: Strengthening or Overburdening the System?". Paper presented at a joint LSE/RIIA conference at Chatham House, London, May 30th 1996. 